\title{
DYNAMICS OF SPRING RUNOFF FLUCTUATIONS FOR THE RIVERS OF THE DON AND DNIEPER BASINS IN THE BELGOROD REGION
}

\author{
Prof. DSc. Andrey Kornilov \\ PG. Vladimir Reshetnikov \\ Assist. Prof. Evgeniya Kornilova \\ Assoc. Prof. Maria Lebedeva \\ Belgorod National Research University, Russia
}

\begin{abstract}
This article is based on the results of studying the dynamics of long-term fluctuations in the flow of spring floods of the Don and Dnieper river basins in the territory of the Belgorod Region in the period 1968-2018. The object of the study are the maximum water discharges during the spring flood on the Tikhaya Sosna river near the town of Alekseevka (right tributary of the Don river) and Vorskla river near the village of Kozinka (left tributary of the Dnieper river). These rivers were chosen as objects of study due to the fact, that the analysis of the zonal and azonal distribution of runoff over the territory of the Belgorod region allows us to correlate their main characteristics as close in values. The flow dynamics during the flood period for the rivers of the Don and Dnieper basins has a negative trend. The decrease in the river flow of the flood, which is typical for the most part of The Russian plain, occurs mainly under the influence of climatic factors, whose contribution to the decrease in the value of modern runoff is estimated at $80 \%$. The values of the maximum flow rates of the Tykhaya Sosna river and the Vorskla river have pronounced fluctuations over the years depending on meteorological conditions. The main factors influencing them, are: water storage in snow before snowmelt, the intensity of the snowmelt and rainfall period, high water, humidity and the degree of freezing of soils and the presence of an ice crust on the soil surface. Thus, the determining factors affecting the nature of the formation of the maximum costs of the spring flood of the Tikhaya Sosna and Vorskla rivers are the growth of average annual temperatures in the catchment area of these basins. This factor also causes a decrease in the depth of soil freezing. This causes large losses of water for infiltration and leads to a pronounced shortage of river flow.
\end{abstract}

Keywords: hydrological regime, the maximum runoff, climatic factors, flooding.

\section{INTRODUCTION}

The values of the maximum flood discharge of the same river can vary significantly over the years depending on meteorological conditions. The main factors affecting them are the amount of water in the snow before snowmelt, the intensity of snowmelt, the amount of rainfall during the flood period, moisture and freezing of soil and bottom sediments, ice crust on soil surface.

The formation of runoff in flood for small and medium rivers of the Belgorod region is also variable. General climatic factors, as well as snow reserves and intensity of 
snowmelt, that change under the influence of zonal and azonal factors combination, have a great influence on water yield duration [1].

\section{MATERIALS AND METHODS}

This article is based on the results of studying the dynamics of long-term fluctuations in the runoff of spring floods of the Don and Dnieper river basins in the territory of the Belgorod Region. The objects of the study are the maximum water discharges during the spring flood on the Tikhaya Sosna river near the town of Alekseevka (right tributary of the Don river) and Vorskla river near the village of Kozinka (left tributary of the Dnieper river). These rivers were chosen as objects of study due to the fact, that the analysis of the zonal and azonal distribution of runoff over the territory of the Belgorod region allows us to correlate their main characteristics as close in values [9]. The rivers have a correlated catchment area and comparable values of runoff index. The data of instrumental observations of hydrological posts with an observation period of at least 50 years (1968-2018) is used (Table 1).

Table 1: Existing hydrological posts (stations) of the Central Chernozem AHEM on Tikhaya Sosna river and the Vorskla river

\begin{tabular}{|c|c|c|c|c|c|}
\hline $\begin{array}{c}\text { Name of water } \\
\text { body }\end{array}$ & $\begin{array}{c}\text { Location (name) of } \\
\text { the post }\end{array}$ & $\begin{array}{c}\text { Distance } \\
\text { from the } \\
\text { mouth, km }\end{array}$ & Catchment area, $\mathrm{km}^{2}$ & $\begin{array}{c}\text { Post zero } \\
\text { mark, m }\end{array}$ & $\begin{array}{c}\text { Opened, } \\
\text { dd.mm.yy }\end{array}$ \\
\hline \multicolumn{7}{|c|}{ Don river basin } \\
\hline $\begin{array}{c}\text { Tikhaya Sosna } \\
\text { river }\end{array}$ & Alekseevka town & 87 & 2060 & $89.93 \mathrm{BS}$ & $\begin{array}{c}15.07 .1941 \\
(08.08 .1949)\end{array}$ \\
\hline \multicolumn{7}{|c|}{ Dnieper river basin } & $119.29 \mathrm{BS}$ & $\begin{array}{c}22.08 .1914 \\
(01.09 .1947)\end{array}$ \\
\hline
\end{tabular}

Data processing was carried out through the application of methods for summarizing hydrometeorological information and methods for establishing statistical relationships between hydrological variables [1], [11].

\section{RESULTS}

To analyze the climatic conditions affecting the surface nutrition of the rivers during the spring flood period, we used data from the M-2 Valuyki meteorological stations (for the Tikhaya Sosna river) and M-2 Gotnya (for the Vorskla river) [5]. Table 2 summarizes the meteorological characteristics of the considered river basins [10]. 
Table 2: Meteorological characteristics of the considered river basins according to the data of M-2 Valuyki and M-2 Gotnya during the flood period (1968-2018)

\begin{tabular}{|c|c|c|c|}
\hline Parameter & $\begin{array}{c}\text { Climate normal } \\
\text { value }(1961-1990)\end{array}$ & Actual value & $\begin{array}{l}\text { Deviation from } \\
\text { the normal } \\
\text { value }\end{array}$ \\
\hline \multicolumn{4}{|c|}{ M-2 Valuyki } \\
\hline Air temperature, ${ }^{\circ} \mathrm{C}$ & -3.8 & -2.7 & +1.1 \\
\hline Precipitation, $\mathrm{mm}$ & 32.5 & 35.3 & +2.8 \\
\hline $\begin{array}{l}\text { The average height of the snow cover, } \\
\mathrm{cm}\end{array}$ & 15 & 12 & -3 \\
\hline $\begin{array}{l}\text { The average supply of water in the } \\
\text { snow, mm }\end{array}$ & 44 & 31 & -13 \\
\hline Depth of soil freezing, $\mathrm{cm}$ & 64 & 39 & -25 \\
\hline \multicolumn{4}{|c|}{ M-2 Gotnya } \\
\hline Air temperature, ${ }^{\circ} \mathrm{C}$ & -4.5 & -3.5 & +1.0 \\
\hline Precipitation, $\mathrm{mm}$ & 35.5 & 38.6 & +3.1 \\
\hline $\begin{array}{l}\text { The average height of the snow } \\
\text { cover, } \mathrm{cm}\end{array}$ & 18 & 16 & -2 \\
\hline $\begin{array}{l}\text { The average supply of water in the } \\
\text { snow, mm }\end{array}$ & 57 & 43 & -14 \\
\hline Depth of soil freezing, $\mathrm{cm}$ & 68 & 38 & -20 \\
\hline
\end{tabular}

According to meteorological observations, an increase in the average long-term air temperatures was recorded. The average long-term increase in air temperature during the flood period for the territory of the Tikhaya Sosna river basin was $+1.1^{\circ} \mathrm{C}$. For the territory of the Vorskla river basin growth of this indicator was $+1.0^{\circ} \mathrm{C}$.

The dynamics of temperature changes at both weather stations has a pronounced positive trend [9].

The average annual rainfall during the watersheds of the rivers under consideration also have a positive deviation from the climatic normal value [6]. For the territory of the Tikhaya Sosna river basin excess was $2.8 \mathrm{~mm}$ ( $8.6 \%$ of the climatic normal value). For the territory of the Vorskla river basin excess was $3.1 \mathrm{~mm}(8.7 \%$ of the climatic normal value).

The underlying surface factors also have an effect on the rate of melt water transfer from snow to soil, accumulating and redistributing it both inside the snow cover and on the surface of the basin, as well as in the soil [11].

The determining parameters in this regard are the snow cover height, water reserves in the snow and the depth of soil freezing [7], which also have pronounced deviations from climatic normal values with a general negative trend in the sampled area. The range of these deviations was $20-39 \%$ for the territory of the Tikhaya Sosna river basin and 12$29 \%$ for the Vorskla river basin.

The observed climatic picture causes changes in river runoffs [3]. This process is illustrated in Fig. 1-2. 


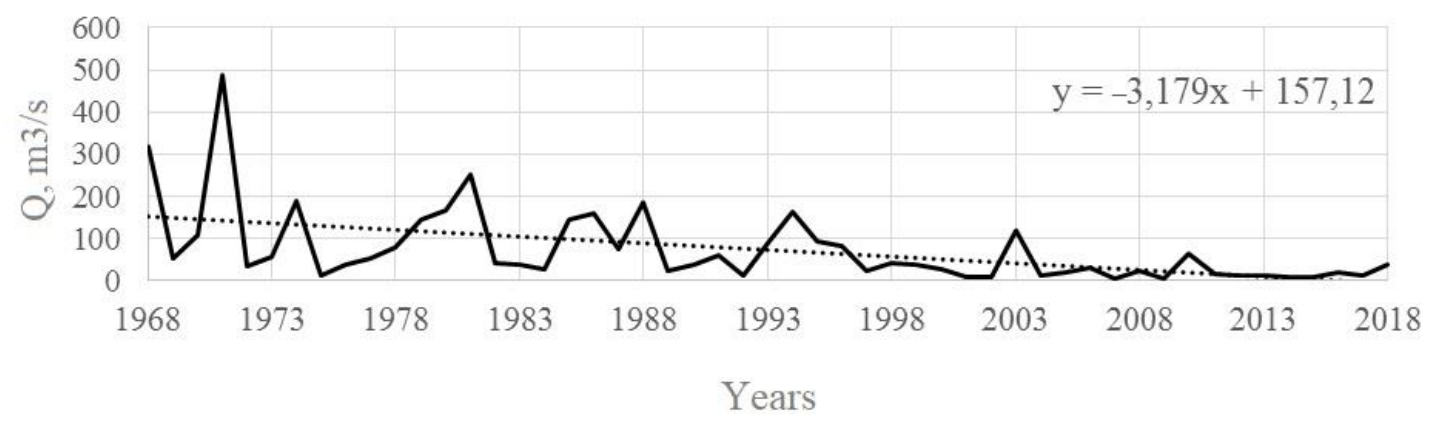

Fig. 1. Maximum water discharge on the Tikhaya Sosna river (Alekseevka)

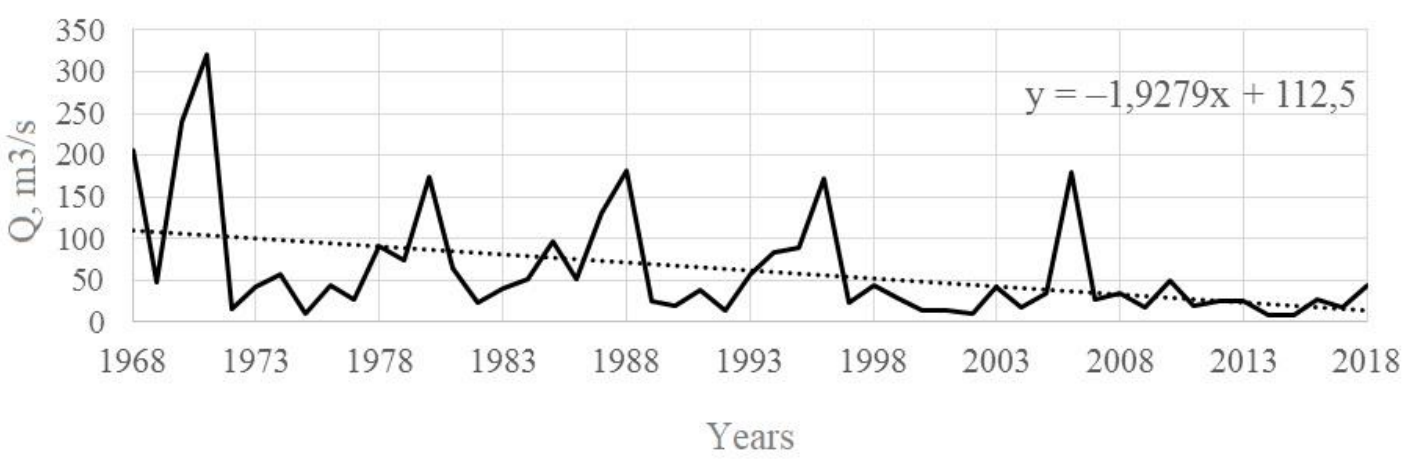

Fig 2. Maximum water discharge on the Vorskla river (Kozinka)

The highest flood discharges are usually formed in friendly spring with heavy snowfall and low losses due to infiltration (wet and commercial soils with an ice crust on its surface) [1]. In a multi-year retrospective, the nature of the flood of Tikhaya Sosna and Vorskla rivers is increasingly departing from these possibilities. According to the decrease in the surface slope runoff, which occurs mainly under the influence of climatic factors, the decrease in the river runoff of the flood is generally typical for most of the Russian Plain [4].

Factors, affecting the dynamics of fluctuations in the spring runoff of the studied rivers within the Belgorod region, are of a similar nature. The dynamics of runoff during the flood period for the rivers of the Don and Dnieper basins has a negative trend. Meanwhile, the amount of precipitation and air temperature during the study period show a positive trend. The parameter of water reserve in the snow with maintaining the height of the snow cover within normal limits has a similar growth. However, the depth of soil freezing decreases over the years. It should be noted that this trend is typical for the entire territory of the Belgorod region [7].

It must be emphisized that the formation of the maximum spring flood in the Belgorod region has a number of zonal features. To identify them, we performed a multivariate analysis of the correlations of the flow-forming parameters of the studied rivers (Table $3)$. 
Table 3: Multivariate analysis of correlations of flow-forming parameters of the Tikhaya Sosna and Vorskla rivers (1968-2018)

\begin{tabular}{|c|c|c|c|}
\hline Parameter & $\begin{array}{l}\text { Maximum water } \\
\text { discharge }\end{array}$ & $\begin{array}{l}\text { Average annual } \\
\text { indexes of winter } \\
\text { rainfall }\end{array}$ & $\begin{array}{l}\text { Average annual } \\
\text { indexes of air } \\
\text { temperature during } \\
\text { the flood period }\end{array}$ \\
\hline \multicolumn{4}{|c|}{ Tikhaya Sosna river } \\
\hline Maximum water discharge & 1.00 & - & - \\
\hline $\begin{array}{l}\text { Average annual indexes of } \\
\text { winter rainfall }\end{array}$ & -0.10 & 1.00 & - \\
\hline $\begin{array}{l}\text { Average annual indexes of } \\
\text { air temperature during the } \\
\text { flood period }\end{array}$ & -0.37 & 0.12 & 1.00 \\
\hline $\begin{array}{l}\text { The average height of the } \\
\text { snow cover }\end{array}$ & 0.01 & -0.05 & 0.03 \\
\hline $\begin{array}{c}\text { The average supply of } \\
\text { water in the snow }\end{array}$ & 0.01 & -0.09 & 0.05 \\
\hline Depth of soil freezing & 0.08 & 0.00 & 0.12 \\
\hline \multicolumn{4}{|c|}{ Vorskla river } \\
\hline Maximum water discharge & 1.00 & - & - \\
\hline $\begin{array}{l}\text { Average annual indexes of } \\
\text { winter rainfall }\end{array}$ & 0.24 & 1.00 & - \\
\hline $\begin{array}{l}\text { Average annual indexes of } \\
\text { air temperature during the } \\
\text { flood period }\end{array}$ & -0.42 & 0.03 & 1.00 \\
\hline $\begin{array}{l}\text { The average height of the } \\
\text { snow cover }\end{array}$ & -0.09 & 0.22 & 0.13 \\
\hline $\begin{array}{l}\text { The average supply of } \\
\text { water in the snow }\end{array}$ & -0.06 & 0.34 & 0.09 \\
\hline Depth of soil freezing & 0.18 & -0.08 & 0.03 \\
\hline
\end{tabular}

Correlation analysis indicates that the height of the snow cover and the water supply in the snow have a more pronounced effect on the maximum runoff for the rivers of the Dnieper basin than for the rivers of the Don basin ( 9 and 6 times respectively). The same can be said about the parameter of the depth of soil freezing, the correlation index with the maximum water discharge for which was 0.1 for the Tikhaya Sosna river and 0.2 for the Vorskla river.

\section{DISCUSSION}

Thus, one of the determining factors, affecting the nature of the formation of the maximum discharges of spring flood of Tikhaya Sosna and Vorskla rivers, is the increase in average annual temperatures in the catchment area of these basins. So, the correlation between the maximum water discharge of the spring flood and the average long-term air temperature of the flood period is -0.3 for the Tikhaya Sosna river basin and -0.4 for the Vorskla river basin. An increase in temperatures in winter led to a decrease in the depth of soil freezing, which is also reflected in other authors research 
[8]. Together, these factors cause large losses of water for infiltration and lead to a pronounced shortage of river runoff.

\section{CONCLUSION}

The maximum water discharge of spring flood in the Belgorod region in the period 1968-2018 have undergone pronounced changes and have a negative tendency. Among the main reasons, we can single out a softening of winter air temperature and a stable trend for its increase, which is the important catalyst for natural hydrological processes [2].

According to meteorological observations on the territory of the studied basins, the increase in the average long-term air temperatures by $1.0-1.1^{\circ} \mathrm{C}$ was recorded. This indicator has a tangible correlation with the maximum water discharges of spring floods $(-0.3$ for the Tikhaya Sosna river basin and -0.4 for the Vorskla river basin).

The increase in temperatures in winter led to a decrease in the depth of soil freezing, which is also reflected in other authors research [8]. The correlation between this factor and the maximum water discharge is 0.1 for the Tikhaya Sosna river basin and 0.2 for the Vorskla river basin.

The average annual indexes of rainfall during floods for the catchments of the studied rivers have a positive deviation from the climatic normal value [7]. For the territory of the Tikhaya Sosna river basin excess was $2.8 \mathrm{~mm}$ ( $8.6 \%$ of the climatic normal value). For the territory of the Vorskla river basin excess was $3.1 \mathrm{~mm}(8.7 \%$ of the climatic normal value). However, the increase in the intensity of melt water transfer from snow to soil, together with a combination of the previously mentioned factors, cause large losses of water for infiltration and lead to a pronounced shortage of river flow.

It is worth highlighting some features of the formation of the maximum discharges of spring flood in the territory of the Belgorod region. The multivariate analysis of the correlations of the flow-forming parameters revealed that the height of the snow cover and the water supply in the snow have a more pronounced effect on the maximum runoff for the rivers of the Dnieper basin than for the rivers of the Don basin (9 and 6 times respectively). The same can be said about the parameter of the depth of soil freezing, the correlation index with the maximum water discharge for which was 0.1 for the Tikhaya Sosna river and 0.2 for the Vorskla river.

\section{REFERENCES}

[1] Bogoslovsky, B.B., Samokhin A.A., Ivanov K.E., Sokolov D.P., General hydrology, Gidrometeoizdat, Leningrad, 424 p, 1984.

[2] Dmitrieva V.A., Sushkov A.I., Dynamics of hydrological regime of upper Don basin rivers and ecological aspects of water use, Modern ecology: education, science, practice: Materials of the international scientific and practical conference, Voronezh, vol. 1, 528 p, 2017.

[3] Kornilov A.G., Lebedeva M.G., Gordeev L.Y., The contribution of precipitation of the warm period of the year the water flow in the rivers of Belgorod region, Belgorod State University Scientific Bulletin, Natural sciences, vol. 20 (15), pp 151-155, 2012

[4] Koronkevich N.A., Dolgov S.V., Kashutina E.A., Hydroecological state of catchments of forest-steppe and steppe zones of The Russian plain, Ecological and 
geographical studies in river basins: Proceedings of the fifth all-Russian scientific and practical conference, SCIENCE-YUNIPRESS, Voronezh, 2018, pp 164-169.

[5] Materials of the Belgorod center for Hydrometeorology and environmental monitoring for 1968-2018.

[6] Petin A.N., Lebedeva M.G., Krymskaya O.V., Chendev Y.G., Kornilov A.G., Lupo A.R., Regional manifestation of changes in atmospheric circulation in the central black earth region (by the example of Belgorod region), Advances in Environmental Biology, vol. 8 (10), pp 544-547, 2014.

[7] Petin A.N., Petina M.A., Lebedeva M.G., Dokalova Y.I., Extreme flood situations on the rivers of Belgorod region, Research Journal of Pharmaceutical, Biological and Chemical Sciences, vol. 6, pp 1787-1792, 2015.

[8] Petin A.N., Petina M.A., Lebedeva M.G., Dokalova Y.I., Natural factors of flood situation in the Belgorod region, Problems of nature management and environmental situation in European Russia and neighboring countries: Proceedings of the VI International scientific conference, 2015, pp 280-284.

[9] Reshetnikov V.S., Kornilov A.G., Lebedeva M.G., Zonal and azonal features of the spatial distribution of annual flow characteristics in the Belgorod region, Ecological and geographical studies in river basins: Proceedings of the fifth all-Russian scientific and practical conference, SCIENCE-YUNIPRESS, Voronezh, 2018, pp 229-233.

[10] Scientific and applied reference book "Climate of Russia" (2007), Retrieved from: http://meteo.ru/pogoda-i-klimat/197-nauchno-prikladnoj-spravochnik-klimat-rossii.

[11] Sokolovsky D.L. River flow: Fundamentals of theory and methods of calculation, Gidrometeoizdat, Leningrad, 539 p, 1968. 
